\title{
Resenha
}

Familia, parentalidade e época: um estudo psicanalítico

Daniela Waldman Teperman São Paulo: Escuta/Fapesp, 2014, 256p.

\section{A FAMÍLIA COMO RESÍDUO}

\section{Leda Mariza Fischer Bernardino}

DOI: http//dx.doi.ors/10.11606/issn.1981-1624.v20i1p151-153.

$\int^{0}$

muito instigador quando temos a oportunidade de acompanhar um percurso acadêmico da qualidade de uma autora como Daniela Teperman. Conheci-a nos tempos do Doutorado, quando ela cursava disciplinas para seu Mestrado. Já neste momento sua curiosidade científica e sua capacidade de argumentação chamavam atenção. Daniela deu-me a honra com um convite para participar de suas bancas de Mestrado e Doutorado. Duas ocasiões a mais para admirar sua capacidade de elaboração teórica e de construção de uma lógica argumentativa.

Este livro resulta de seu texto de Doutorado e já no prefácio temos o prazer de ler o texto de Rinaldo Voltolini, orientador do trabalho, que entre outras afirmações, diz: "Aos cidadãos de nossa época esse livro deixa uma questão fundamental: $O$ que significa apostar tanto, como temos feito contemporaneamente, na perspectiva de uma juridização das relações e na promoção de práticas cada vez mais pautadas na figura do especialista e do saber científico?" (p. 11). Já neste prefácio somos apresentados, enquanto leitores, à leitura fina que a autora nos proporcionará sobre o discurso social atual a respeito da família. 
O livro traz à luz uma discussão pouco explorada pelos psicanalistas, e, justamente por isso, prima por seu ineditismo e pela diferença de pensamento em relação ao discurso politicamente correto em torno das questões ditas "de gênero". É sobre o termo parentalidade que Teperman se interroga: "Será que a família, ao assumir-se como uma 'parentalidade', finalmente se verá livre dos excessos e das faltas inerentes à transmissão familiar?” (p. 15). Isso mostra, como arguta pesquisadora, que a dita "parentalidade só faz impasse quando tomada de uma forma redutora, aniquiladora da família em sua condição de resíduo" (p. 17). Este é o conceito-chave de sua tese, a família resíduo, que lhe permite demonstrar como a estrutura da família resiste, apesar das mudanças contingenciais em cada época. Para chegar nesta ideia a autora trabalha, no primeiro capítulo, a família na Psicanálise de orientação lacaniana. Faz não só uma retomada do clássico e fundamental texto de Lacan sobre $A$ Família, como vai até suas origens durkheimianas, chegando a várias releituras contemporâneas deste escrito lacaniano, realizadas por autores como Sauret e Miller, e fazendo até uma referência à Carta ao pai, de Kafka.

O segundo capítulo é dedicado às mudanças no contexto histórico, mudanças na família. Neste, a autora se apoia em Derrida e sua ideia de "trans-historicidade do laço familiar" (p. 81), embora afirme: "articular estrutura e história não é uma simples empreitada" (p. 99). Podemos dizer que Teperman enfrenta este desafio muito bem acompanhada. Além de Lacan, Chemama e Askofaré também a auxiliam neste desafio. Referindo-se ao discurso do capitalista e ao discurso científico, situa o mal-estar na atualidade de um modo muito engenhoso, com o exemplo do filme Aonde vivem os monstros. Por meio desta alegoria demonstra como as ilusões da modernidade são insustentáveis, "contudo, se viver juntos é mal-estar, o filme mostra que as soluções de cada um diante do mal-estar são singulares e contingenciais" (p. 109). Esta crítica contra as generalizações apressadas é a marca do livro.

Em "A parentalidade como o sintomático desta época", terceiro capítulo deste livro, Teperman analisa os vários contextos do uso desta palavra que nomeia como um "neologismo" definido assim: “o termo 'parentalidade' se institui no vácuo da discussão sobre o declínio da função paterna e evidencia, no mesmo movimento que o forja, um mal-estar relativo ao desempenho das funções parentais" (p. 123). Com isso, mostra como o novo termo ao mesmo tempo que escamoteia, é um sintoma deste mal-estar.

152 Estilos clin., São Paulo, v. 20, n.1, jan./abr. 2015, 151-153. 
Em uma jogada de gênio, no quarto capítulo, Teperman disseca um livro interessantíssimo lançado por uma autora francesa, uma das "filhas" da geração de Maio de 68. Este material precioso lhe serve de exemplo para mostrar como cada época é lida com os significantes particulares de cada sujeito e interpretada sem as generalizações que costumam ser utilizadas, principalmente pelos sociólogos. Ela denuncia que este "nós" não existe. Dos "filhos de 68" pesquisados, não foi possível fazer classe!

Com o título "A parentalidade para todos, não sem a família de cada um", a autora apresenta suas conclusões, afirmando: "a família faz furo, descompleta a parentalidade" (p. 204); "a função residual da família fura a consistência do genérico parentalidade" (p. 205). Conclui Teperman que "uma época não conforma a um 'nós' os sujeitos que dela fazem parte” (p. 206), e termina seu livro com esta importante chave de ouro: "A família tende a continuar abrindo furos na consistência e na assepsia previstas nos discursos normativos e ortopédicos sobre a parentalidade" (p. 208).

Isto é o que se espera de um psicanalista que incida nas certezas, aponte as brechas, quebre as hegemonias, dê lugar aos sujeitos. Quando isso é feito com o respaldo de um exemplar percurso acadêmico, todos nós agradecemos! 